\title{
Exploring Interpersonal Touch in Computer Games
}

\author{
Cody Watts \\ University of Calgary \\ 2500 University Drive NW \\ Calgary, AB, Canada \\ wattsc@cpsc.ucalgary.ca
}

\author{
Ehud Sharlin \\ University of Calgary \\ 2500 University Drive NW \\ Calgary, AB, Canada \\ ehud@cpsc.ucalgary.ca
}

\author{
Peter Woytiuk \\ BioWare Corp. \\ 200, 4445 Calgary Trail \\ Edmonton, $A B$, Canada \\ woytiuk@bioware.com
}

\begin{abstract}
Acts of interpersonal touch are used by couples to communicate with their partner in a simple, lightweight and emotionally significant way. In this abstract, we briefly present our motivation and initial design approach for Matchmaker - a cooperative, romantically-themed game for tabletop computers which integrates acts of interpersonal into its game mechanics.
\end{abstract}

\section{Categories and Subject Descriptors}

H.5.2 [Information interfaces and presentation]: User Interfaces

- Input devices and strategies, interaction styles.

K.8.0 [Personal Computing]: General - Games.

\section{General Terms}

Design.

\section{Keywords}

Computer games, interpersonal touch.

\section{INTRODUCTION}

Interpersonal touch - an act of physical contact shared between two people - is one of the most emotionally-significant ways that human beings communicate. Intimate behaviors like handholding, hugging and kissing are commonly used as a method of expressing affection between couples. However, findings by Crusco et al. \& Fisher et al. suggests that even a fleeting touch from a stranger can improve one's overall mood [1, 2].

We believe that computer games can leverage the emotional connections created by interpersonal touch to create an emotionally-engaging gameplay experience for couples. To support this notion, we present our initial design approach for Matchmaker: a cooperative, two-player computer game which detects and reacts to acts of interpersonal touch (e.g. handholding) between its players.
Permission to make digital or hard copies of all or part of this work for personal or classroom use is granted without fee provided that copies are not made or distributed for profit or commercial advantage and that copies bear this notice and the full citation on the first page. To copy otherwise, to republish, to post on servers or to redistribute to lists, requires prior specific permission and/or a fee.

Advances in Computer Entertainment Technology 2008, Yokohama, Japan. Copyright 2008 ACM 978-1-60558-393-8/08/12 ...\$5.00.

\section{MATCHMAKER}

Using interpersonal touch as interaction technique presents a unique challenge, since players may feel conspicuous about touching their partner as they play. Our goal in designing Matchmaker was to create an environment in which players would feel confident to hold hands with their partner as they play. Since touch is so often used as an expression of love and romance, it seemed only fitting that Matchmaker be a romantically-themed game whose cutesy, heart-filled appearance would reflect the affectionate behavior of its hand-holding players.

In Matchmaker, players must work together to create matches between Peeps - the small love-starved people who inhabit the world of Matchmaker. By touching and dragging compatible Peeps together with their partner, players can create matches and increase their score. There's only one caveat: players must act quickly, because Peeps which remain single for too long will become depressed and lovelorn. When a Peep becomes lovelorn, it will start to cry and it cannot be matched with any other Peep. There's only one cure for a lovelorn Peep - players must join hands, and touch the affected Peep to rejuvenate it's faith in the Power of Love. A lovelorn Peep which has been cured in this way becomes ready to find love once again, and can now be matched up with other Peeps.

\section{CONCLUSION}

We have presented our initial design approach for Matchmaker -a cooperative, romantically themed game for tabletop computers designed to help us explore interpersonal touch interaction in games.

We hope to present our completed implementation of Matchmaker, along with an evaluation of the game and its use of interpersonal touch soon.

\section{REFERENCES}

[1] Crusco, A., Wetzel, C. 1984. "The Midas Touch: The Effects of Interpersonal Touch on Restaurant Tipping” Personality and Social Psychology Bulletin, Vol. 10, No. 4, (512-517).

[2] Fisher, J. D., Rytting, M., and Heslin, R. 1976. "Hands touching hands: Affective and evaluative effects of an interpersonal touch.” Sociometry 39 (416-421). 